\title{
Transglutaminase activity is involved in Saccharomyces cerevisiae wall construction
}

\author{
María Iranzo, Carmen Aguado, Claudia Pallotti, Jose V. Cañizares \\ and Salvador Mormeneo
}

Author for correspondence: Salvador Mormeneo. Tel: +3496 3864682. Fax: +34963864682.

e-mail: salvador.mormeneo@uv.es

Sección de Microbiología Facultad de Farmacia, Universidad de Valencia, Avda V. Andrés Estelles s/n, 46100 Burjassot (Valencia), Spain

\begin{abstract}
Transglutaminase activity, which forms the interpeptidic cross-link $\boldsymbol{N}^{\varepsilon}$ - $(\gamma-$ glutamyl)-lysine, was demonstrated in cell-free extracts of Saccharomyces cerevisiae by incorporation of $\left[{ }^{14} \mathrm{C}\right]$ lysine into an exogenous acceptor, $N, N^{\prime}$ dimethylcasein. Higher levels of the activity were present in the cell wall, which also contained endogenous acceptors. The enzyme activity in the wall was inhibited by cystamine, a known inhibitor of transglutaminase, and by EDTA, indicating a cation-dependent activity. After the endogenous wall acceptors were labelled radioactively by transglutaminase, extraction with SDS solubilized about $50 \%$ of the total radioactivity, while Zymolyase and chitinase each released a further $3 \%$. The proteins solubilized by SDS had molecular masses less than $50 \mathrm{kDa}$, whereas the material released by Zymolyase or chitinase had molecular masses greater than $180 \mathrm{kDa}$, suggesting a precursor-product relationship. Cystamine inhibited the growth of several strains of S. cerevisiae. Treated cells showed increased sensitivity to Zymolyase and appeared as protoplasts, indicating gross alterations in the cell wall. These data suggest that transglutaminase may be involved in the formation of covalent cross-links between wall proteins during wall construction.
\end{abstract}

Keywords: cross-linking, activity inhibition, cell wall, yeast

\section{INTRODUCTION}

The cell wall of Saccharomyces cerevisiae is a wellorganized structure, formed by the association of many components, mainly polysaccharides (glucan and chitin), and proteins. The discovery of proteins anchored through GPI linkages (Klis, 1994; Vossen et al., 1997) and of the Pir proteins (Mrsa et al., 1997), were significant advances in the knowledge of cell wall construction, at least in certain fungal species (Kapteyn et al., 1999, 2000; Smits et al., 1999). Covalent linkages among the wall components forming supramolecular complexes called 'building blocks' have been described in yeast (Kollar et al., 1997). Recently, it has been reported that the Gas family of proteins may act as a wall polymer cross-linker (Fonzi, 1999; Popolo \& Vai, 1999).

Previously, we described the presence of transglutaminase (TGase) activity in the walls of Candida

Abbreviation: TGase, transglutaminase. albicans, producing covalent cross-links between proteins. Inhibition of this enzyme decreased the covalent incorporation of several proteins, which, in turn, disrupted both the regeneration of protoplasts and the yeast-mycelium transition (Ruiz-Herrera et al., 1995). Moreover, the cell wall acceptors of TGase activity have been shown to be virulence determinants of C. albicans (Staab et al., 1999; Sundstrom, 1999).

TGases (EC 2.3.2.13) catalyse covalent cross-linking between proteins by forming an amide bond between the $\gamma$-carboxyamide group of appropriate peptide-bound glutamine moieties and the $\varepsilon$-amino group of specific peptide-bound lysine residues (Folk, 1980). TGases with different physiological roles have been described in mammals, plants and other organisms (Ichinose et al., 1990; Serafini-Fracassini et al., 1995; Chandrashekar \& Mehta, 2000), many related to the formation of resistant structures having protective functions. A TGase immunologically related to mammalian TGase catalyses crosslinking of the cell wall in the green alga Chlamydomonas reinhardtii (Waffenschmidt et al., 1999) and recently, using computer analysis, proteins with homology to 
eukaryotic TGases have been described in S. cerevisiae and Schizosaccharomyces pombe (Makarova et al., 1999).

Here, we present evidence of a TGase activity in the wall of $S$. cerevisiae; the effects of its inhibition by cystamine suggest that it plays important roles in the organization of the cell wall.

\section{METHODS}

Strains and culture conditions. The strain used in this study was Saccharomyces cerevisiae X2180-1A; other S. cerevisiae strains were used for comparative experiments only. Yeast strains were grown in YPD medium (1\% yeast extract, $2 \%$ Bacto Peptone, $2 \%$ glucose) to early exponential phase; in some experiments cystamine was added to the concentrations indicated in the text. Solid medium was obtained by adding $\operatorname{agar}(2 \%)$.

Preparation of cell-free extracts. Cell-free extracts were obtained by breaking cells with glass beads in a Braun cell homogenizer, in $50 \mathrm{mM}$ Tris $/ \mathrm{HCl}(\mathrm{pH} 7 \cdot 4)$, containing $1 \mathrm{mM}$ phenylmethylsulfonyl fluoride and $1 \mu \mathrm{g}$ pepstatin $\mathrm{A} \mathrm{ml}^{-1}$. The extracts were centrifuged at $2000 \mathrm{~g}$ to pellet the cell walls, which were washed twice in $50 \mathrm{mM}$ phosphate buffer, twice with $2 \mathrm{M} \mathrm{NaCl}$ and twice with distilled water. The supernatant was centrifuged at $40000 \mathrm{~g}$ in a Beckman JA 20 rotor to separate the membrane fraction (pellet) from the cytosol (supernatant). Alternatively, to obtain small amounts of purified walls, the cells, mixed with glass beads, were broken by agitating on a Vortex mixer for $30 \mathrm{~s}$ periods, with cooling periods of $1 \mathrm{~min}$ in an ice bath until all of the cells were disrupted, and treated as above. In each case, breakage was assessed by phase-contrast microscopy.

TG assay. TG activity of the different fractions was quantitated by incorporation of a radioactively labelled amine substrate, as previously described (Barsigian et al., 1988; Simon \& Green, 1985), except that $\left[{ }^{14} \mathrm{C}\right]$ lysine was used instead of $\left[{ }^{3} \mathrm{H}\right]$ putrescine. TGase reaction mixture was in a final volume of $1 \mathrm{ml} 50 \mathrm{mM}$ Tris $/ \mathrm{HCl}(\mathrm{pH} 7 \cdot 4)$ containing $2.5 \mu \mathrm{Ci}$ $(92.5 \mathrm{kBq})\left[{ }^{14} \mathrm{C}\right]$ lysine $\left(9 \cdot 2 \mathrm{mCi} \mathrm{mmol}^{-1}, 340 \cdot 4 \mathrm{MBq} \mathrm{mmol}^{-1}\right)$ and enzymic fraction. Following $5 \mathrm{~h}$ incubation at $30^{\circ} \mathrm{C}$ with shaking, the reaction was stopped by addition of $2 \mathrm{ml} 10 \%$ TCA.

After at least $2 \mathrm{~h}$ on ice, samples were centrifuged; the pellet was resuspended in $2.5 \mathrm{ml} 10 \%$ TCA, heated in a boiling water bath for $10 \mathrm{~min}$, and recentrifuged. Sediment was washed twice with $10 \%$ TCA, twice with $5 \%$ TCA and twice with ethanol prior to measurement of radioactivity. To determine TGase activity using the endogenous wall acceptors, the same protocol was used without the addition of $N, N^{\prime}$-dimethylcasein as exogenous acceptor.

Solubilization of wall proteins, gel electrophoresis and fluorography. Purified walls labelled with $\left[{ }^{14} \mathrm{C}\right]$ lysine were sequentially solubilized with SDS, Zymolyase (Miles Laboratories) and chitinase (Sigma), as previously described (Ruiz-Herrera et al., 1995). Released proteins were separated from the insoluble residue by centrifugation $(3000 \mathrm{~g}, 10 \mathrm{~min}$ ) and the radioactivity measured. Samples containing 10000 c.p.m. were subjected to electrophoresis and subsequent fluorography, as has been described (Ruiz-Herrera et al., 1995). The molecular masses were determined by reference to molecular mass markers (Bio-Rad).

Analysis of sensitivity to cystamine. The method for testing the sensitivity of $S$. cerevisiae strains exposed to different concentrations of cystamine was similar to that described by van der Vaart et al. (1995). Briefly, the different strains were grown to early exponential phase and diluted to an $\mathrm{OD}_{600}$ of $0 \cdot 4\left(3 \times 10^{6}\right.$ cells $\left.\mathrm{ml}^{-1}\right) ; 3 \mu \mathrm{l}$ aliquots containing approximately $10^{4}$ cells or $1 / 10$ serial dilutions of each culture were spotted onto a series of YPD plates containing varying amounts $(0$ to $100 \mathrm{mM}$ ) cystamine. Differences in the growth of the strains were recorded after incubation of the plates at $28^{\circ} \mathrm{C}$ for $48 \mathrm{~h}$.

Analysis of sensitivity to Zymolyase. S. cerevisiae X2180-1A cells from early exponential culture, incubated in the presence or absence of cystamine, were adjusted to an $\mathrm{OD}_{600}$ of 0.5 in $10 \mathrm{mM}$ Tris $/ \mathrm{HCl}(\mathrm{pH} 7 \cdot 5)$ containing $25 \mu \mathrm{g}$ Zymolyase $20 \mathrm{~T} \mathrm{ml}^{-1}$. The decreases in optical density were monitored over 10 min periods, according to the method of van der Vaart et al. (1995).

\section{RESULTS}

\section{TGase activity in cell-free extracts of S. cerevisiae}

In animal systems, where the role of TGase is well established (Folk, 1980; Lorand \& Conrad, 1984), the enzyme activity has been measured by the incorporation of radioactive putrescine into TCA-precipitable material (Barsigian et al., 1988; Simon \& Green, 1985). A similar protocol was used to determine the presence of this enzymic activity in C. albicans, which resulted in problems with nonspecific adsorption (Ruiz-Herrera et al., 1995). When $\left[{ }^{3} \mathrm{H}\right]$ putrescine or $\left[{ }^{14} \mathrm{C}\right]$ lysine were compared as substrates for TGase during the present

Table 1. Distribution of TGase activity in cell-free extracts of $S$. cerevisiae

Total TGase activity was determined by measuring the amount of $\left[{ }^{14} \mathrm{C}\right]$ lysine incorporated into TCA-precipitable material, in the presence or absence of $50 \mathrm{mM}$ cystamine. The specific and relative activities were calculated from the total activity. The values are means of four determinations \pm SD.

\begin{tabular}{|c|c|c|c|c|}
\hline Fraction & $\begin{array}{l}\text { Total activity } \\
\text { (c.p.m.) }\end{array}$ & $\begin{array}{l}\text { Specific activity } \\
{\left[\mathrm{c} \cdot \mathrm{p} \cdot \mathrm{m} . \mathrm{h}^{-1}(\mathrm{mg}\right.} \\
\left.\text { protein })^{-1}\right]\end{array}$ & $\begin{array}{c}\text { Relative } \\
\text { activity ( } \%)\end{array}$ & $\begin{array}{l}\text { Total activity in } \\
\text { the presence of } \\
\text { cystamine (c.p.m.) }\end{array}$ \\
\hline Cell walls & $30707 \pm 1480$ & 6141 & 67 & $187 \pm 12$ \\
\hline Mixed membranes & $19735 \pm 1075$ & 2631 & 29 & $147 \pm 10$ \\
\hline Cytosol & $1202 \pm 65$ & 384 & 4 & $136 \pm 12$ \\
\hline
\end{tabular}




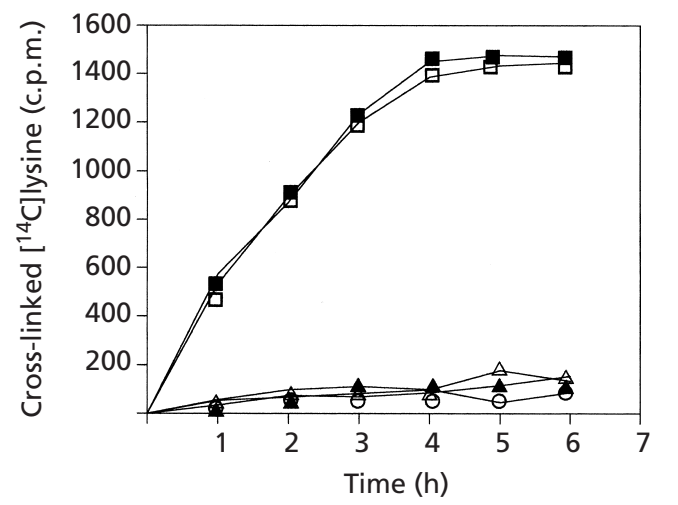

Fig. 1. TGase-mediated incorporation of $\left[{ }^{14} \mathrm{C}\right]$ lysine into endogenous cell wall proteins. Similar aliquots of cell walls containing $2.5 \mu \mathrm{Ci}\left[{ }^{14} \mathrm{C}\right]$ lysine without $(\boldsymbol{\square})$ or with cycloheximide $(\square)$, boiled $(\boldsymbol{\Delta})$, with $50 \mathrm{mM}$ cystamine $(\triangle)$ or with EDTA $2 \mathrm{mM}(O)$ were incubated for the indicated times, and the TCA-p recipitable radioactivity was measured as described in Methods.

study no significant differences in enzyme activity were found (data not shown) and there were no problems with nonspecific adsorption. The suitability of lysine as a substrate for TGase was confirmed by comparing the incorporation of radioactivity from $\left[{ }^{3} \mathrm{H}\right]$ putrescine or $\left[{ }^{14} \mathrm{C}\right]$ lysine into $\mathrm{N}, \mathrm{N}^{\prime}$-dimethylcasein using TGase from guinea pig liver (Sigma; data not shown). Initial experiments with $S$. cerevisiae TGase were performed using a cell-free extract as the enzyme source and, as shown in Table 1 , most of the enzymic activity was present in the cell wall, whereas only minimal activity was detected in the cytosol. In all cases, lysine incorporation was inhibited by cystamine, an active-sitedirected TGase inhibitor (Lorand \& Conrad, 1984; Barsigian et al., 1988).

Purified cell walls incorporated $\left[{ }^{14} \mathrm{C}\right]$ lysine in a timedependent fashion up to $4-5 \mathrm{~h}$ (Fig. 1). The total activity in cell walls was similar to that obtained in the presence of cycloheximide, indicating that the phenomenon was not due to the presence of unbroken cells. The presence of EDTA blocked the TGase activity, producing a background $\left[{ }^{14} \mathrm{C}\right]$ lysine incorporation, similar to that produced by cystamine or the use of boiled preparations (Fig. 1). Wall TGase activity was dependent on the presence of divalent cations. For a control incubation of $1368 \pm 60$ c.p.m. $\left[{ }^{14} \mathrm{C}\right]$ lysine incorporated (mean \pm sD, 4 determinations), $\mathrm{Ca}^{2+}$ and $\mathrm{Mg}^{2+}$ increased the TGase activity (1782 \pm 76 c.p.m. incorporated, $130 \%$ control; and $1573 \pm 35$ c.p.m. incorporated, $115 \%$ control, respectively), whereas $\mathrm{Co}^{2+}, \mathrm{Ba}^{2+}$ and $\mathrm{Mn}^{2+}$ decreased the activity $(679 \pm 16$ c.p.m. incorporated, $50 \%$ control; $798 \pm 25$ c.p.m. incorporated, $58 \%$ control; $311 \pm 7$ c.p.m. incorporated, $23 \%$ control, respectively).

To investigate the nature of the endogenous acceptor of TGase in the walls, purified walls were incubated in the presence of $\left[{ }^{14} \mathrm{C}\right]$ lysine as described, sequentially extracted with SDS, Zymolyase (which contains $\beta$ -

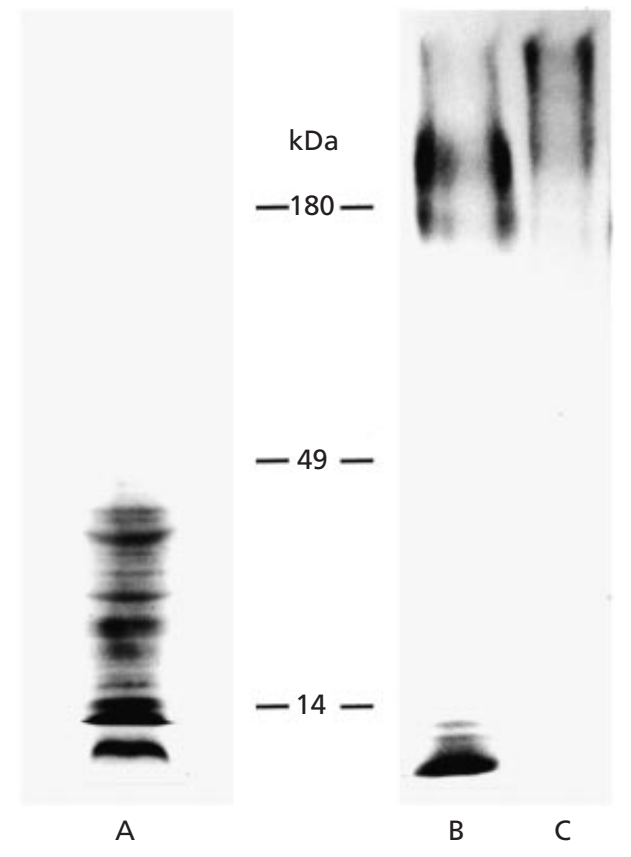

Fig. 2. Fluorography of proteins labelled with $\left[{ }^{14} \mathrm{C}\right]$ lysine and released from the cell walls by sequential SDS (lane $A$ ), Zymolyase (lane B) and chitinase (lane C) treatments. Aliquots of each solubilized fraction containing 10000 c.p.m. were analysed by SDS-PAGE and fluorography as described in Methods.

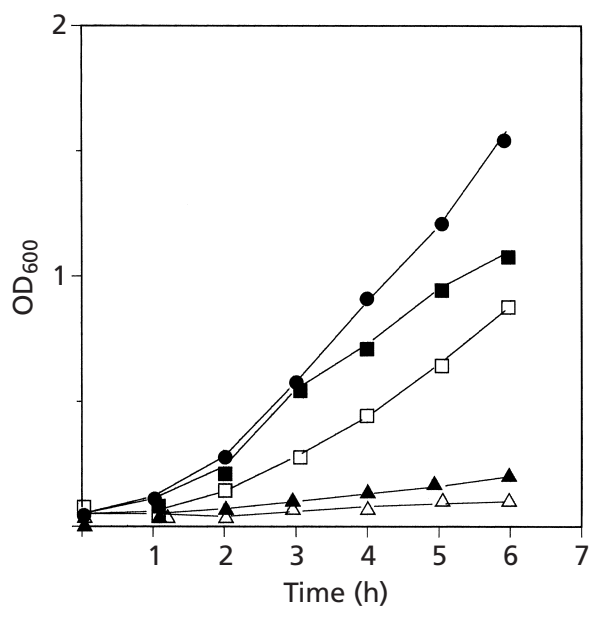

Fig. 3. Effect of cystamine on the growth of $S$. cerevisiae X2180-1A in liquid medium. Exponentially growing cells were incubated in YPD liquid medium in the absence $(\mathbf{)}$ or presence of cystamine $50 \mathrm{mM}(\boldsymbol{\square}), 100 \mathrm{mM}(\square), 200 \mathrm{mM}(\boldsymbol{\Delta})$ and $400 \mathrm{mM}(\triangle)$. The $\mathrm{OD}_{600}$ of the cultures was measured as described in Methods.

glucanase activity) and chitinase, and radioactivity in the solubilized fractions was measured. The fractions were analysed by SDS-PAGE and fluorography. From the total amount of radioactivity incorporated into the wall by action of the TGase activity $80700 \pm 4100$ c.p.m. 

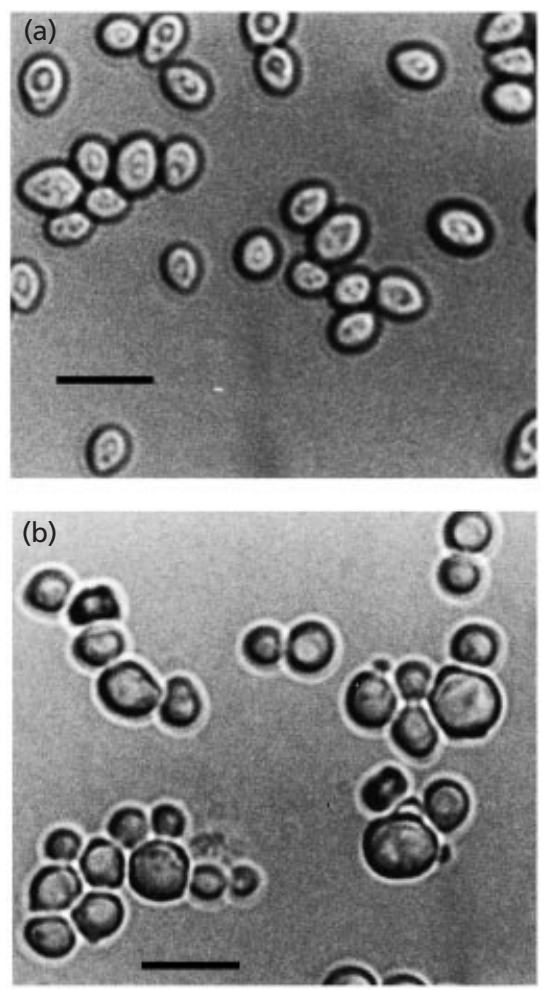

Fig. 4. Microscopic observation of the effect of cystamine on $S$. cerevisiae cells growing in liquid medium. Cells incubated for $4 \mathrm{~h}$ in the absence (a) or presence (b) of cystamine (50 mM) were examined by phase-contrast microscopy. Bars, $10 \mu \mathrm{m}$.

(mean $\pm \mathrm{sD}, 3$ determinations), SDS solubilized $39600 \pm 1600$ c.p.m. (49\% of the total radioactivity), while $\bar{Z}$ ymolyase and chitinase each released only a further $3 \%$ of the total radioactivity $(2200 \pm 140$ c.p.m. and $2370 \pm 150$ c.p.m., respectively). The proteins solubilized by SDS had apparent molecular masses less than $50 \mathrm{kDa}$, and most of the material released by Zymolyase or chitinase showed a molecular mass greater than $180 \mathrm{kDa}$ (Fig. 2).

\section{Effect of TGase inhibition on cell growth of S. cerevisiae}

To determine whether protein cross-linking through TGase is an important reaction in the formation of the cell wall of $S$. cerevisiae, we made use of cystamine. Increasing concentrations of cystamine in liquid medium proportionally reduced the rate of growth of $S$. cerevisiae strain X2180-1A, with $200 \mathrm{mM}$ cystamine almost completely inhibiting growth (Fig. 3). Microscopic examination revealed the presence of abnormal cells, which increased in volume and assumed a spherical morphology similar to protoplasts (Fig. 4). In the presence of sorbitol $(1 \mathrm{M})$, as osmotic stabilizer, the morphology of the cells was not altered following incubation in growth medium containing cystamine, although growth was inhibited. Moreover, the addition of water to the incubation caused an osmotic shock leading to the formation of abnormal growth forms similar to those described above (data not shown).

The sensitivity to cystamine of different strains of $S$. cerevisiae was tested in solid medium (Fig. 5). The growth of all of the strains was inhibited by cystamine, although the strains showed differing sensitivities to the compound. S. cerevisiae X2180-1A and TR93 grew in the presence of $50 \mathrm{mM}$ cystamine, while the growth of strains Cen.pK2 and Cy7 was reduced markedly at $25 \mathrm{mM}$ cystamine.

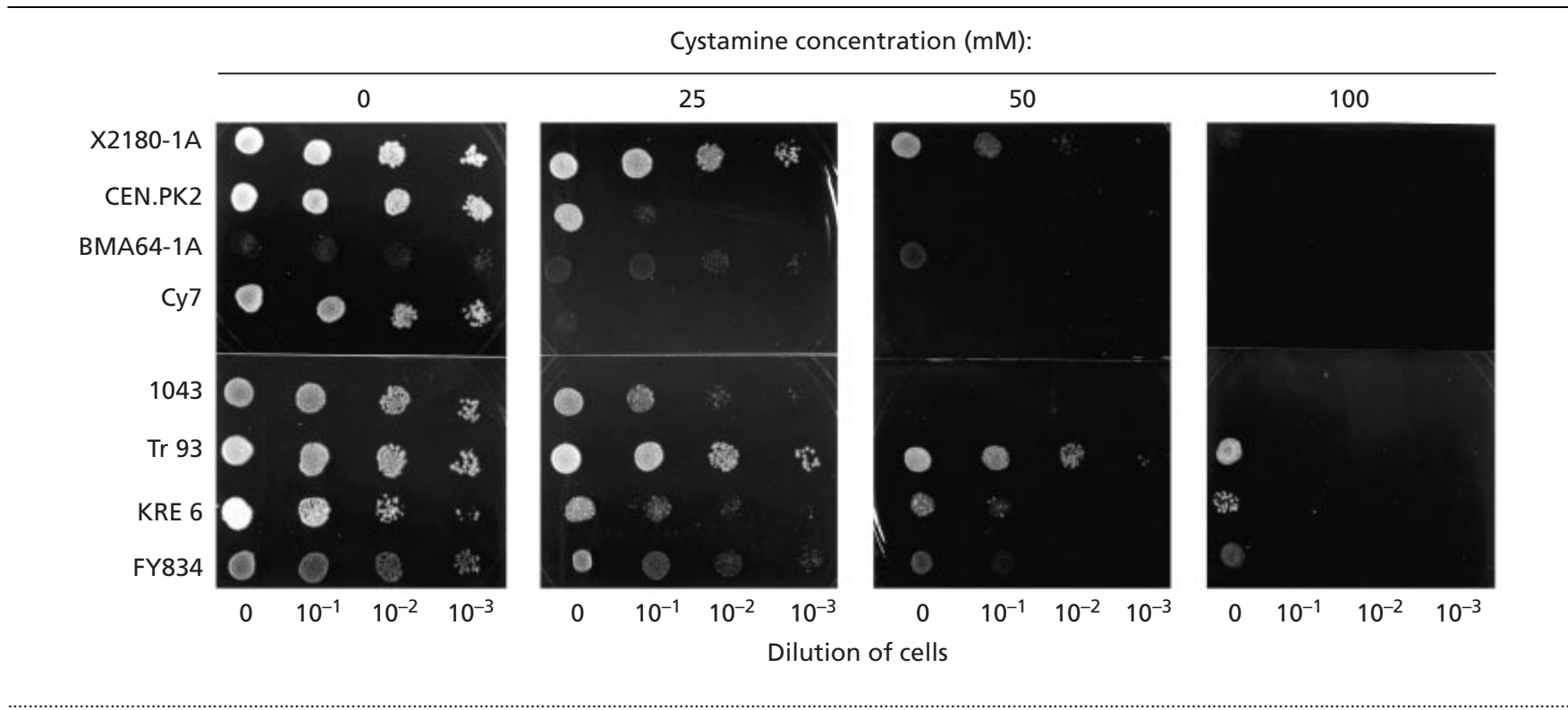

Fig. 5. Effect of cystamine on the growth in solid medium of different strains of S. cerevisiae. Cells were grown in YPD and a $1 / 10$ dilution series of the $S$. cerevisiae strains indicated (initial cell concentration $3 \times 10^{6}$ cells $\mathrm{ml}^{-1}$ ) was used to inoculate the same medium containing agar, and cystamine at 0, 25, 50 and $100 \mathrm{mM}$ as described in Methods. 


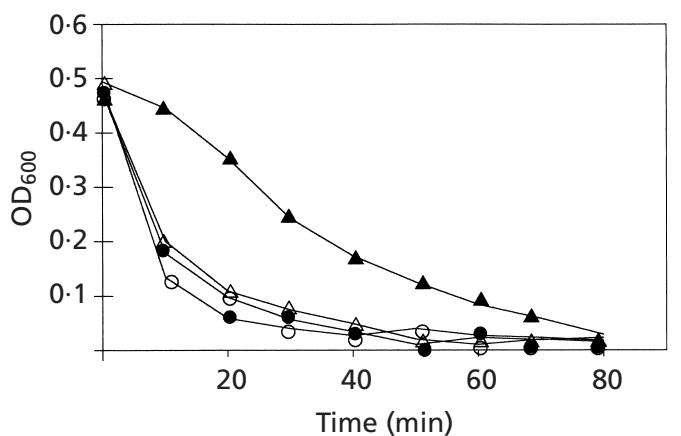

Fig. 6. Sensitivity of $S$. cerevisiae cells to Zymolyase. Cells in the exponential phase of growth were incubated without $(\boldsymbol{\Delta})$ or with $100 \mathrm{mM}$ cystamine for $2 \mathrm{~h}(\triangle), 4 \mathrm{~h}(\mathbf{O})$ or $6 \mathrm{~h}(\bigcirc)$. Cells were washed, adjusted to an $\mathrm{OD}_{600}$ of 0.5 , incubated in Zymolyase 20T $\left(25 \mathrm{mg} \mathrm{ml}^{-1}\right)$ and the decrease in $\mathrm{OD}_{600}$ monitored as described in Methods.

\section{Sensitivity to Zymolyase}

The sensitivity of yeast cells to Zymolyase has been used to monitor changes in cell wall composition and arrangement (de Nobel et al., 1990; Ram et al., 1994; van der Vaart et al., 1995). When S. cerevisiae X2180-1A cells were incubated for 2,4 and $6 \mathrm{~h}$ in the presence of $100 \mathrm{mM}$ cystamine, the sensitivity to Zymolyase digestion increased with respect to the cells incubated without cystamine (Fig. 6).

\section{DISCUSSION}

Covalent linkages among $S$. cerevisiae wall components that give rise to supramolecular complexes have been described and these contribute to our understanding of the molecular architecture of the cell wall (Kapteyn et al., 2000). The study of the assembly processes for cell wall construction is a challenging task and the next goal will be the identification of the cross-linking enzymes.

Using $\left[{ }^{14} \mathrm{C}\right]$ lysine as precursor, most of the radioactivity cross-linked in the cell wall (Table 1), whereas only residual binding was detected in the cytosol. A similar radioactive distribution was demonstrated for C. albicans (Ruiz-Herrera et al., 1995), and in both fungal species the cross-linking was inhibited by cystamine, indicating a TGase-mediated process. Almost $30 \%$ of $S$. cerevisiae TGase was in a membrane preparation and this enzyme might be a precursor of the wall TGase. However, TGase activity functioning intracellularly has been described in other systems (Thacher \& Rice, 1985; Chowdhury et al., 1997).

Whereas TGases in higher animals always require $\mathrm{Ca}^{2+}$ for activity, $\mathrm{Ca}^{2+}$ is not essential for TGase activity in plants and micro-organisms (Aeschlimann \& Paulsson, 1994; Chandrashekar \& Mehta, 2000). Although the different cations had differing effects on wall TGase activity, as already described for hepatocyte TGase (Barsigian et al., 1988), this experiment was not definitive because the wall can have a natural back- ground of cations. The results suggest that other cations were, in general, less effective than $\mathrm{Ca}^{2+}$ in supporting TGase activity, and the fact that EDTA inhibited the enzymic activity (Fig. 1) supports the hypothesis that wall TGase activity is dependent on divalent cations.

To investigate the distribution of endogenous acceptors of TGase in cell walls, the enzyme reaction was carried out in the presence of purified walls that later were sequentially solubilized by SDS, to release noncovalently linked proteins, and with Zymolyase and chitinase, in order to solubilize the proteins cross-linked covalently to polysaccharides. SDS solubilized approximately $50 \%$ of the radioactivity apparently cross-linked by the wall TGase; Zymolyase and chitinase subsequently released only small amounts $(3 \%)$, in contrast to the higher proportions of covalently linked wall proteins that others report being solubilized by $\beta$ glucanases and chitinase (Klis, 1994; Kapteyn et al., 1999). The fact that high levels of the proteins apparently labelled radioactively by the wall TGase were resistant to the hydrolytic enzymes ( $45 \%$ ) suggests the existence of unknown proteinaceous material forming part of the core of the wall structure.

The apparent TGase acceptors released by SDS had low molecular masses $(\leqslant 50 \mathrm{kDa})$ in contrast to the predominantly high molecular masses of the materials released by Zymolyase or chitinase ( $\geqslant 180 \mathrm{kDa}$ ) (Fig. 2), suggesting a possible precursor-product relationship. That is, the measurable molecular mass of SDS-soluble TGase acceptors may have increased as these acceptors were cross-linked to the wall by TGase activity. This type of high-molecular-mass material, which was described by others as a product of TGase activity (Barsigian et al., 1988; Martinez et al., 1989), had a similar electrophoretic mobility to the wall supramolecular complexes termed 'building blocks' (Kollar et al., 1997; Kapteyn et al., 1999). Thus, S. cerevisiae TGase may be involved in the formation of these supramolecular complexes.

To determine whether protein cross-linking through TGase is important for the growth of S. cerevisiae, we made use of the TGase inhibitor cystamine (Simon \& Green, 1985; Martinez et al., 1989). Adding cystamine to the liquid growth medium reduced the level of growth of $S$. cerevisiae X2180-1A proportionally to the concentration of the inhibitor (Fig. 3). Cystamine also altered the cell morphology (Fig. 4), and increased the sensitivity of cells to Zymolyase (Fig. 6). These results suggest that inhibition of growth by cystamine is due, at least in part, to the effect of cystamine on cell wall TGase activity.

Recently, using computer analysis, proteins with homology to eukaryotic TGases were detected, for the first time, in S. cerevisiae and Schizosaccharomyces pombe (Makarova et al., 1999). S. cerevisiae disruptants of the genes YPL096 and YDL117W, detected as candidates for TGase genes by computer analysis, were purchased from Euroscarf, and no significant differences between TGase activities in these strains and in wild-type 
organisms were detected (data not shown). Moreover, the YPL096W/PNG1/LPG12 gene encodes a soluble protein that, when expressed in Escherichia coli, exhibits peptide N-glycanase activity (Suzuki et al., 2000) while the YDL117W/CYK3/D2275 gene encodes a protein possibly involved in cytokinesis (Zhu et al., 2000). Thus there is no obvious relationship between these gene products and the TGase activity characterized during the present study. However, from the results presented here we conclude that TGase activity is indeed present in $S$. cerevisiae, where it plays important roles in cell wall organization.

\section{ACKNOWLEDGEMENTS}

This work was supported by grants from the Dirección General de Investigaciones Científica y Técnica (PM96-0019 and BMC01-2761) and from the Generalitat de Valencia (CAPA00-03). J.V.C. was supported by a post-doctoral 'Primo-Yufera' fellowship from the Jose y Ana Royo Fundation.

\section{REFERENCES}

Aeschlimann, D. \& Paulsson, M. (1994). Transglutaminases: protein cross-linking enzymes in tissues and body fluids. Thromb Haemostasis 71, 402-415.

Barsigian, C., Fellin, F. M., Jain, A. \& Martinez, J. (1988). Dissociation of fibrinogen and fibronectin binding from transglutaminase-mediated cross-linking at the hepatocyte surface. J Biol Chem 263, 14015-14022.

Chandrashekar, R. \& Mehta, K. (2000). Transglutaminasecatalyzed reactions in the growth, maturation and development of parasitic nematodes. Parasitol Today 16, 11-17.

Chowdhury, Z. A., Barsigian, C., Chalupowicz, G. D., Bach, T. L., Garcia-Manero, G. \& Martinez, J. (1997). Colocalization of tissue transglutaminase and stress fibers in human vascular smooth muscle cells and human umbilical vein endothelial cells. Exp Cell Res 231, 38-49.

de Nobel, J. G., Klis, F. M., Priem, J., Munnik, T. \& van den Ende, H. (1990). The glucanase-soluble mannoproteins limit cell wall porosity in Saccharomyces cerevisiae. Yeast 6, 491-499.

Fonzi, W. A. (1999). PHR 1 and PHR 2 of Candida albicans encode putative glycosidases required for proper cross-linking of beta1,3- and beta-1,6-glucans. J Bacteriol 181, 7070-7079.

Folk, J. E. (1980). Transglutaminases. Annu Rev Biochem 49, 517-531.

Ichinose, A., Bottenus, R. E. \& Davie, E. W. (1990). Structure of transglutaminases. J Biol Chem 265, 13411-13414.

Kapteyn, J. C., van Den Ende, H. \& Klis, F. M. (1999). The contribution of cell wall proteins to the organization of the yeast cell wall. Biochim Biophys Acta 1426, 373-383.

Kapteyn, J. C., Hoyer, L. L., Hecht, J. E., Muller, W. H., Andel, A., Verkleij, A. J., Makarow, M., van den Ende, H. \& Klis, F. M. (2000). The cell wall architecture of Candida albicans wild-type cells and cell wall-defective mutants. Mol Microbiol 35, 601-611.

Klis, F. M. (1994). Cell wall assembly in yeast. Yeast 10, 851-869. Kollar, R., Reinhold, B. B., Petrakova, E., Yeh, H. J., Ashwell, G., Drgonova, J., Kapteyn, J. C., Klis, F. M. \& Cabib, E. (1997). Architecture of the yeast cell wall $\beta(1,6)$-glucan interconnects mannoprotein, $\beta(1,3)$-glucan, and chitin. J Biol Chem 272, 17762-17775.

Lorand, L. \& Conrad, S. M. (1984). Transglutaminases. Mol Cell Biochem 58, 9-35.

Makarova, K. S., Aravind, L. \& Koonin, E. V. (1999). A superfamily of archaeal, bacterial, and eukaryotic proteins homologous to animal transglutaminases. Protein Sci 8, 1714-1719.

Martinez, J., Rich, E. \& Barsigian, C. (1989). Transglutaminasemediated cross-linking of fibrinogen by human umbilical vein endothelial cells. J Biol Chem 264, 20502-20508.

Mrsa, V., Seidl, T., Gentzsch, M. \& Tanner, W. (1997). Protein specific labelling of cell wall proteins by biotinylation. Identification of four covalently linked $\mathrm{O}$-mannosylated proteins of Saccharomyces cerevisiae. Yeast 13, 1145-1154.

Popolo, L. \& Vai, M. (1999). The Gas1 glycoprotein, a putative wall polymer cross-linker. Biochim Biophys Acta 1426, 385-400.

Ram, A. F., Wolters, A., Ten Hoopen, R. \& Klis, F. M. (1994). A new approach for isolating cell wall mutants in Saccharomyces cerevisiae by screening for hypersensitivity to calcofluor white. Yeast 10, 1019-1030.

Ruiz-Herrera, J., Iranzo, M., Elorza, M. V., Sentandreu, R. \& Mormeneo, S. (1995). Involvement of transglutaminase in the formation of covalent cross-links in the cell wall of Candida albicans. Arch Microbiol 164, 186-193.

Serafini-Fracassini, D., Del Duca, S. \& Beninati, S. (1995). Plant transglutaminases. Phytochemistry 40, 355-365.

Simon, M. \& Green, H. (1985). Enzymatic cross-linking of involucrin and other proteins by keratinocyte particulates in vitro. Cell 40, 677-683.

Smits, G. J., Kapteyn, J. C., van den Ende, H. \& Klis, F. M. (1999). Cell wall dynamics in yeast. Curr Opin Microbiol 2, 348-352.

Staab, J. F., Bradway, S. D., Fidel, P. L. \& Sundstrom, P. (1999). Adhesive and mammalian transglutaminase substrate properties of Candida albicans Hwp1. Science 283, 1535-1538.

Sundstrom, P. (1999). Adhesins in Candida albicans. Curr Opin Microbiol 2, 353-357.

Suzuki, T., Park, H., Hollingsworth, N. M., Sternglanz, R. \& Lennarz, W. J. (2000). PNG1, a yeast gene encoding a highly conserved peptide: N-glycanase. J Cell Biol 149, 1039-1052.

Thacher, S. M. \& Rice, R. H. (1985). Keratinocyte-specific transglutaminase of cultured human epidermal cells: relation to crosslinked envelope formation and terminal differentiation. Cell 40, 685-695.

van der Vaart, J. M., Caro, L. H., Chapman, J. W., Klis, F. M. \& Verrips, C. T. (1995). Identification of three mannoproteins in the cell wall of Saccharomyces cerevisiae. J Bacteriol 177, 3104-3110.

Vossen, J. H., Muller, W. H., Lipke, P. N. \& Klis, F. M. (1997). Restrictive glycosylphosphatidylinositol anchor synthesis in cwh6/gpi3 yeast cells causes aberrant biogenesis of cell wall proteins. J Bacteriol 179, 2202-2209.

Waffenschmidt, S., Kusch, T. \& Woessner, J. P. (1999). A transglutaminase immunologically related to tissue transglutaminase catalyzes cross-linking of cell wall proteins in Chlamydomonas reinhardtii. Plant Physiol 121, 1003-1015.

Zhu, G., Spellman, P. T., Volpe, T., Brown, P. O., Botstein, D., Davis, T. N. \& Futcher, B. (2000). Two yeast forkhead genes regulate the cell cycle and pseudohyphal growth. Nature 406, 90-94.

Received 2 July 2001; revised 4 January 2002; accepted 15 January 2002. 